\title{
Penerapan Model Pembelajaran Penemuan Terbimbing untuk Meningkatkan Hasil Belajar Fisika pada Siswa Kelas XI IPA SMA GKST Palu
}

\author{
Elsa Krisye Natalia Kopi, Yusuf Kendek dan H. Muhammad Ali \\ e-mail: nataliaelsa@ymail.com \\ Program Studi Pendidikan Fisika FKIP Universitas Tadulako \\ Jl. Soekarno Hatta Km. 9 Kampus Bumi Tadulako Tondo Palu - Sulawesi Tengah
}

\begin{abstract}
Abstrak - Penelitian ini bertujuan untuk meningkatkan hasil belajar fisika siswa kelas XI IPA SMA GKST Palu. Kelas XI IPA ini memiliki 14 siswa yang terdiri 6 siswa laki - laki dan 8 siswa perempuan. Penelitian Tindakan Kelas ini mengikuti rancangan model Kemmis dan Mc. Taggart, yang dilakukan dalam dua siklus, dengan tiap siklus melalui 4 tahap, yaitu : (1) Perencanaan, (2) Pelaksanaan, (3) Observasi, dan (4) Refleksi. Berdasarkan analisis hasil belajar siswa pada siklus I didapatkan ketuntasan klasikal $100 \%$ dan daya serap klasikal sebesar 98,67 \%. Pada siklus II ketuntasan belajar klasikal sebesar $100 \%$ dan daya serap klasikal sebesar 99,00 \%. Pada siklus I dan II untuk ketuntasan klasikal yang didapatkan telah memenuhi indikator keberhasilan yaitu diatas $80 \%$. Hasil observasi siswa pada siklus I pertemuan 1 sebesar $64,28 \%$ dan pertemuan 2 sebesar 75,00 $\%$. Pada siklus II hasil observasi siswa sebesar 89,28 \%. Hasil observasi siswa pada penelitian ini menunjukkan adanya peningkatan dari siklus I ke siklus II dan berada pada kateori sangat baik. Sedangkan untuk hasil observasi guru pada siklus I pertemuan 1 sebesar 71,86 \% dan pertemuan 2 sebesar 78,13 \%. Pada siklus II hasil observasi guru sebesar 90,62 \%. Hasil observasi guru yang diperoleh memperlihatkan bahwa terjadi peningkatan persentasi dari siklus I ke siklus II hingga berada pada kategori sangat baik. Berdasarkan indikator maka dapat disimpulkan bahwa penerapan model pembelajaran penemuan terbimbing dapat meningkatkan hasil belajar fisika siswa.
\end{abstract}

Kata Kunci : hasil belajar fisika, model pembelajaran penemuan terbimbing.

\section{PENDAHULUAN}

Ilmu Pengetahuan Alam (IPA) termasuk dalam mata pelajaran yang cenderung kurang diminati para anak didik. Termasuk didalamnya Fisika. Guru memegang peranan penting dalam menentukan kualitas dan kuantitas pembelajaran yang dilaksanakan. Oleh karena itu, guru harus dapat memikirkan dan memilih berbagai strategi mengajar serta menggunakan strategi tersebut sesuai dengan tujuan pengajaran yang ingin dicapai.

Terkait dengan hal di atas, metode yang cocok dengan kondisi siswa agar siswa dapat berpikir kritis, logis dan dapat memecahkan masalah dengan sikap terbuka, kreatif, dan inovatif, salah satunya adalah model pembelajaran penemuan (discovery learning).

Balim [1] dalam penelitiannya menyatakan bahwa penggunaan metode pembelajaran penemuan ini merupakan salah satu dari berbagai metode pengajaran, di mana siswa belajar dengan aktif dan dibimbing oleh guru, sehingga dapat meningkatkan hasil belajar dan keterampilan belajar siswa.

Oghenevwede [2] dalam penelitiannya menyatakan bahwa metode penemuan (discovery) lebih unggul dan lebih efektif dibandingkan dengan metode penyelidikan (inkuiri). Oleh karena itu guru sains harus konsisten menggunakan pendekatan penemuan dalam mengajar biologi.

Zulhelmi [3] dalam penelitiannya menyatakan bahwa dalam pendekatan penemuan terbimbing memungkinkan guru dapat menerapkan penilaian psikomotor dan melihat respon siswa (afektif), karena langkahlangkah dalam pembelajaran Guided Discovery dapat digunakan sebagai alat melatih psikomotor siswa dan menanamkan respon positif siswa terhadap pembelajaran fisika.

Satyawati [4] dalam penelitiannya menyatakan bahwa hasil belajar matematika siswa yang mengikuti pelajaran dengan model pembelajaran penemuan terbimbing berbasis LKS lebih tinggi daripada hasil belajar matematika siswa yang mengikuti pelajaran dengan model pembelajaran konvensional. Tingginya hasil belajar siswa yang mengikuti pembelajaran dengan model penemuan terbimbing tidak terlepas dari keaktifan siswa dalam kegiatan pembelajaran, siswa mempergunakan ide, konsep dan ketrampilan yang sudah mereka pelajari untuk menemukan pengetahuan baru dan menarik kesimpulan. 
Yusnawan [5] dalam penelitiannya menyatakan bahwa melalui penerapan metode penemuan terbimbing dapat mengindikasikan aktivitas pembelajaran mengalami peningkatan dan indikator keberhasilan tindakan tercapai.

RUMUSAN MASALAH

"Apakah Penerapan Model Pembelajaran Penemuan Terbimbing dapat meningkatkan hasil belajar Fisika pada siswa kelas XI IPA di SMA GKST PALU?"

\section{TUJUAN}

Tujuan Penelitian ini adalah untuk meningkatkan hasil belajar Fisika melalui penerapan model pembelajaran penemuan terbimbing pada siswa kelas XI IPA SMA GKST PALU.

\section{METODE PENELITIAN}

Penelitian ini adalah penelitian tindakan kelas. Pelaksanaan penelitian tindakan kelas ini, mengikuti tahap penelitian tindakan yang tiap tahap disebut siklus. Rancangan penelitian ini mengacu pada model Kemmis dan Mc. Taggart.

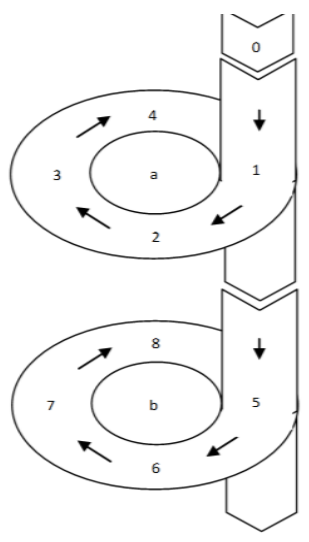

$\begin{array}{cl}\text { Keterangan: } \\ 0 & \text { :Pra Tindakan } \\ 1 & : \text { Rencana siklus 1 } \\ 2 & : \text { pelaksanaan tindakan kelas 1 } \\ 3 & : \text { Observasi siklus 1 } \\ 4 & : \text { Refleksi siklus 1 } \\ 5 & : \text { Rencana siklus 2 } \\ 6 & : \text { pelaksanaaan tindakan kelas 2 } \\ 7 & : \text { Observasi siklus 2 } \\ 8 & : \text { Refleksi siklus 2 } \\ \text { a } & : \text { Siklus 1 } \\ \text { b } & : \text { Siklus 2 }\end{array}$

Gbr. 1.Tahap PTK Model Spiral dari Kemmis dan Mc. Taggart

Penelitian ini dilaksanakan di SMA GKST PALU dan sebagai subjek penelitian adalah siswa kelas XI IPA pada semester gasal tahun ajaran 2015/2016, di mana jumlah siswa 14 orang yang terdiri 6 siswa laki-laki dan 8 siswa perempuan.

\section{HASIL PENELITIAN DAN PEMBAHASAN}

Pada penelitian ini dilakukan observasi aktivitas guru (peneliti) dan siswa selama proses pembelajaran. Pada penelitian ini yang bertindak sebagai observer adalah guru mata pelajaran Fisika di SMA GKST Palu. Observasi siswa dilakukan dengan cara mengamati kegiatan siswa selama proses pembelajaran berlangsung.

Pada siklus I untuk taraf keberhasilan aktivitas siswa dalam pembelajaran berada dalam kategori baik dengan presentase nilai rata - rata sebesar $69,64 \%$, setelah diperoleh masukan dari hasil refleksi pada siklus I, maka aktivitas belajar siswa mengalami peningkatan pada siklus II yaitu sebesar 89,28 \% \% dan berada pada kategori sangat baik.

Sedangkan pada guru (peneliti), observasi dilakukan pada saat mengajar dengan mengacu pada rencana pembelajaran yang kemudian diisi pada lembar observasi. Pada siklus I untuk taraf keberhasilan aktivitas guru dalam pembelajaran berada dalam kategori baik dengan presentase nilai rata-rata sebesar 75,00 $\%$, setelah diperoleh masukan dari hasil refleksi pada siklus I, maka aktivitas guru mengalami peningkatan pada siklus II yaitu sebesar 90,62 $\%$ dan berada pada kategori sangat baik.

Untuk lebih jelasnya peningkatan presentase aktivitas siswa dan guru dapat dilihat pada Tabel 1 dan Gambar 2.

TABEL 1 PRESEntase AKTIVITAS SisWa dan GuRU

\begin{tabular}{|c|c|c|c|}
\hline \multirow{2}{*}{ No } & \multirow{2}{*}{ Aktivitas } & \multicolumn{2}{|c|}{ Presentase Skor } \\
\cline { 3 - 4 } 1 & Siswa & $69,64 \%$ & $89,28 \%$ \\
\hline 2 & Guru & $75,00 \%$ & $90,62 \%$ \\
\hline
\end{tabular}

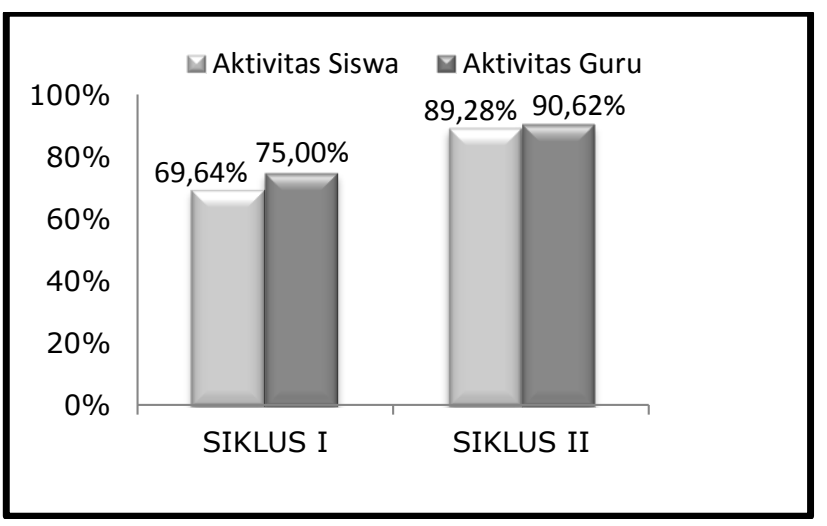

Gambar. 2.Grafik peningkatan persentase aktifitas siswa dan guru

Adapun hasil penilaian tes siswa selengkapnya dari tes awal hingga tes akhir siklus II dapat dilihat pada tabel 2 dan gambar 3. 
TABEL 2 DATA HASIl BeLAJAR SisWA

\begin{tabular}{|c|c|c|}
\hline No & Siklus & Nilai Rata-rata \\
\hline 1 & Pra tindakan & 44,29 \\
\hline 2 & Siklus I & 98,57 \\
\hline 3 & Siklus II & 99,29 \\
\hline
\end{tabular}

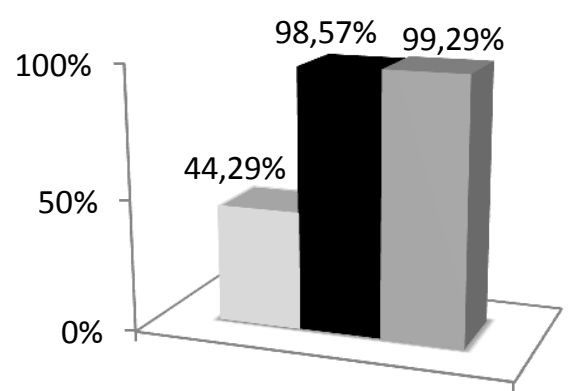

Pra tindakan $\mathbf{S i k l u s ~ I ~}$ Siklus II

Gambar. 3.Grafik hasil tes belajar siswa

Berdasarkan hasil observasi aktivitas siswa dan guru serta hasil analisis tes pada siklus I dan siklus II menunjukkan adanya peningkatan yang sangat baik. Hal ini pun menunjukkan bahwa penggunaan model pembelajaran penemuan terbimbing cukup efektif diterapkan dalam proses belajar mengajar di kelas.

Pada siklus I terdapat beberapa kekurangan saat pembelajaran berlangsung yaitu siswa masih kurang dalam memperhatikan dan menanggapi informasi yang disampaikan guru, kurang menanggapi masalah yang diberikan guru dalam LKS, siswa masih kurang dalam melakukan percobaan serta guru masih kurang dalam memberikan motivasi kepada siswa. Adapun penyebab kekurangan selama proses pembelajaran berlangsung pada siklus I yaitu guru kurang tegas dalam menangani siswa yang ribut dan mengganggu temannya yang lain, siswa merasa ragu dalam mengajukan pendapat dikarenakan takut salah, serta guru (peneliti) yang masih kurang dalam mengontrol siswa dalam melakukan praktikum sehingga hanya siswa tertentu saja yang aktif.

Berdasarkan hasil refleksi pada siklus I, maka ada beberapa hal yang perlu diperhatikan guru (peneliti) untuk memperbaiki kekurangan pada siklus I yaitu lebih tegas dan disiplin dalam mengelolah kelas, memberikan motivasi dan penghargaan kepada siswa yang aktif selama proses pembelajaran serta meminta siswa melakukan pengamatan secara bergantian dan membimbing siswa agar bisa lebih aktif dalam melakukan praktikum. Pada hasil analisis tindakan siklus II terlihat bahwa tidak adanya siswa yang mendapatkan skor terendah. Hal ini menunjukkan kemampuan siswa dalam menyelasaikan soal semakin meningkat dan konsep yang diajarkan oleh guru (peneliti) semakin dipahami dengan baik oleh siswa, sehingga hasil belajar siswa juga meningkat.

\section{KESIMPULAN}

Berdasarkan hasil analisis data yang diperoleh dalam penelitian ini, maka dapat disimpulkan bahwa penerapan model pembelajaran penemuan terbimbing dapat meningkatkan hasil belajar fisika siswa pada kelas XI IPA SMA GKST Palu. Hal ini ditunjukkan dengan adanya peningkatan hasil belajar siswa dari siklus I ke siklus II. Pada siklus I menunjukkan bahwa ketuntasan belajar klasikal telah memenuhi indikator kinerja, aktivitas siswa dan guru berada pada kategori baik serta telah memenuhi indikator kinerja. Pada siklus II juga menunjukkan bahwa ketuntasan belajar klasikal telah memenuhi indikator kinerja, aktivitas siswa dan guru berada pada kategori sangat baik serta telah memenuhi indikator kinerja.

\section{DAFTAR PUSTAKA}

[1] Balim, A. 2009.The Effects of Discovery Learning on StudentsSuccess and Inquiry Learning Skills. Egitim Arastirmalari-Eurasian Journal

EducationalResearch, 35, 1-20.

[2] Oghenevwede. J. 2009. Effects Of Discovery and Inquiry Approaches in Teaching and Learning of Biology on Secondary Schools StudentsPerformance in Delta State, Nigeria. Journal of Research in Education and Society Vol.1 No.1, April 2010. http://www.icidr.org(diakses 12 Juni 2015)

[3] Zulhelmi. 2009. Penilaian Psikomotor dan Respon Siswa dalam Pembelajaran Sains Fisika Melalui Penerapan Penemuan Terbimbing di SMP Negeri 20 Pekanbaru. Jurnal Geliga Sains 3 (2), 8-13, 2009_Program Studi Pendidikan Fisika FKIP Universitas Riau. http://ejournal.unri.ac.id (diakses 12 Juni 2015)

[4] Satyawati, N. N. S. B. 2011. Pengaruh model pembelajaran penemuan terbimbing berbasis LKS terhadap hasil belajar metematika siswa ditinjau dari kecerdasan logis matematis pada siswa kelas $X$ SMAN 1 Bangli. http://pasca.undiksha.ac.id (diakses 8 Juni 2015)

[5] Yusnawan, I. P. A. 2013. Penerapan Metode Penemuan Terbimbing Untuk Meningkatkan Pemahaman Siswa Pada Materi Gradien di Kelas VIII SMP Negeri 9 Palu. http://jurnal.untad.ac.id (diakses 08 Juni 2015) 